\title{
Hazard and risk assessments for induced seismicity in Groningen
}

\author{
Jan van Elk ${ }^{1, *}$, Dirk Doornhof ${ }^{1}$, Julian J. Bommer ${ }^{2}$, Stephen J. Bourne ${ }^{3}$, Steve J. Oates ${ }^{4}$, \\ Rui Pinho ${ }^{5}$ \& Helen Crowley ${ }^{6}$
}

1 Nederlandse Aardolie Maatschappij, B.V., Schepersmaat 2, 9405 TA Assen, the Netherlands

2 Civil \& Environmental Engineering, Imperial College London, London SW7 2AZ, UK

3 Shell Global Solutions International, Gasweg 31, $1031 \mathrm{HW}$ Amsterdam, the Netherlands

4 Shell Global Solutions International, Kessler Park 1, 2288 GS Rijswijk, the Netherlands

5 University of Pavia, Pavia, Italy

6 Seismic Risk Consultant, Pavia, Italy

* Corresponding author. Email: jan.van-elk@shell.com

Manuscript received: 18 April 2017, accepted: 2 0ctober 2017

\section{Abstract}

Earthquakes associated with gas production have been recorded in the northern part of the Netherlands since 1986. The Huizinge earthquake of 16 August 2012, the strongest so far with a magnitude of $M_{\mathrm{L}}=3.6$, prompted reassessment of the seismicity induced by production from the Groningen gas field. An international research programme was initiated, with the participation of many Dutch and international universities, knowledge institutes and recognised experts.

The prime aim of the programme was to assess the hazard and risk resulting from the induced seismicity. Classic probabilistic seismic hazard and risk assessment (PSHA) was implemented using a Monte Carlo method. The scope of the research programme extended from the cause (production of gas from the underground reservoir) to the effects (risk to people and damage to buildings). Data acquisition through field measurements and laboratory experiments was a substantial element of the research programme. The existing geophone and accelerometer monitoring network was extended, a new network of accelerometers in building foundations was installed, geophones were placed at reservoir level in deep wells, GPS stations were installed and a gravity survey was conducted.

Results of the probabilistic seismic hazard and risk assessment have been published in production plans submitted to the Minister of Economic Affairs, Winningsplan Groningen 2013 and 2016 and several intermediate updates. The studies and data acquisition further constrained the uncertainties and resulted in a reduction of the initially assessed hazard and risk.

Keywords: Groningen gas field, hazard assessment, induced seismicity, risk assessment

\section{Introduction}

Since 1986, earthquakes have been recorded near producing gas fields in the provinces of Groningen, Drenthe and Noord-Holland and in northern Germany. In the early 1990s, a multidisciplinary study of these events concluded that the observed earthquakes were of non-tectonic origin and induced by reservoir depletion (i.e. gas production). Following up on this conclusion, a shallow borehole seismometer network was installed in the Groningen area. The network was designed to detect earthquakes, pinpoint their locations and quantify their magnitudes, and has been operational since 1995. Additional accelerometers were installed in areas with highest earthquake density. This seismic monitoring network showed a gradual increase in seismic activity, particularly after 2003.

A renewed focus on the issue of seismicity induced by gas production in Groningen started in 2012 following the earthquake near Huizinge (16 August 2012) with magnitude $M_{\mathrm{L}}=$ 3.6. This earthquake was felt as more intense, with a longer duration, and caused significantly more building damage than previous earthquakes. People living in the Groningen field area have been confronted with increasing intensity of the effects of induced earthquakes (Tomale, 2015), and the Huizinge event has left an especially deep imprint. A programme to study

(C) Netherlands Journal of Geosciences Foundation 2018. This is an Open Access article, distributed under the terms of the Creative Commons Attribution-NonCommercial-NoDerivatives licence (http://creativecommons.org/licenses/by-nc-nd/4.0/), which permits noncommercial re-use, distribution, and reproduction in any medium, provided the original work is unaltered and is properly cited. The written permission of Cambridge University Press must be obtained for commercial re-use or in order to create a derivative work. 


\section{Integrated Hazard and Risk Assessment}

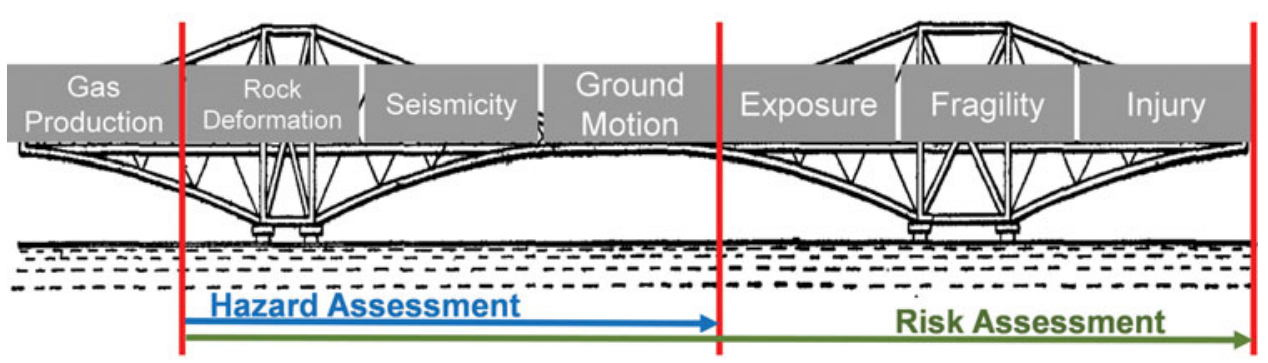

Fig. 1. The causal chain from gas production to safety of people was depicted as a bridge in the 'Study and Data Acquisition Plan' (NAM et al., 2014).

seismicity induced by gas production from the Groningen field and the associated effects on buildings and people living above the field was initiated (NAM et al., 2012, 2014, 2016a,b). This required studies into domains where NAM did not have sufficient expertise. Therefore, the plan mobilised support from Dutch and international universities, knowledge institutes and laboratories and sought the assistance and advice of external recognised experts.

\section{Research into induced seismicity in Groningen}

The seismicity in Groningen differs from typical tectonic earthquakes in three aspects: (1) it is induced by the withdrawal of gas, (2) the shallow subsurface in the Groningen area consists of thick layers of very soft deposits and (3) the buildings in the Groningen area have been designed and constructed without consideration for the horizontal loads typically experienced during an earthquake. Acquisition of data specific to the Groningen area is therefore essential, and data gathering in the field and laboratory experiments are an important part of the research programme. The existing geophone and accelerometer network has been extended to cover the full field, and geophones have been placed at the reservoir level in deep wells. The programme was first described in the 'Study and Data Acquisition Plan' of November 2012 (NAM et al., 2012), which has since been updated several times (NAM et al., 2014, 2016 a,b).

The main objectives of the Study and Data Acquisition Plan are:

1. To understand the impact of the earthquake hazard on buildings and other structures and the subsequent impact on safety of the community;

2. To perform a fully integrated probabilistic hazard and risk assessment for the Groningen region, with all uncertainties fully and consistently recognised and quantified;

3. To identify, evaluate and develop mitigation options to reduce safety risk:

a. Production measures, i.e. changes in the production from the field b. An optimised Structural Safety Upgrading programme

c. Identify buildings and/or building elements that pose a safety risk

d. Establish optimal structural upgrading methodologies;

4. Measures for industry and infrastructure.

Other important objectives are to:

5. Discuss the merits of alternative scientific views, and initiate additional studies and/or data acquisition to promote consensus amongst the knowledge institutes;

6. Monitor compaction, subsidence and seismicity;

7. Continuously improve our understanding of the physical mechanisms leading to induced seismicity and the resulting hazard;

8. Reduce the uncertainty in the hazard and risk assessment.

To achieve these objectives the research programme covered the full causal chain (Fig. 1) from the production of gas to the effects of the earthquakes at the surface, damage to buildings and risk for people. Updates on the impact of the data acquisition and studies of the assessment of hazard and risk were prepared regularly during the execution of the research programme. This also allowed a review of the programme, and identification of additional study requirements. In practice, almost every 6 months an updated hazard and risk assessment was published (NAM, 2013, 2014, $2015 a, b, 2016)$. The aim of the programme was to achieve a well-calibrated hazard and risk assessment for the update of the Winningsplan in July 2016. The intermediary assessments aimed to be conservative in the sense that future updates were more likely to give a reduced assessment of hazard and risk rather than an upwards adjustment (for the same level of gas production).

The model used to assess hazard and risk resulting from induced seismicity in Groningen, is based on the probabilistic seismic hazard and risk assessment (PSHA) methodology introduced by Cornell (1968), which has since become the internationally recognised standard method for seismic risk assessments. This probabilistic risk assessment method fits well with the methods used to determine other risks, such as those resulting from floods, plane crashes around airports and industrial accidents. The Monte Carlo method is used to implement the model. 


\section{Huizinge Event 16-8-2012 (Westeremden station)}
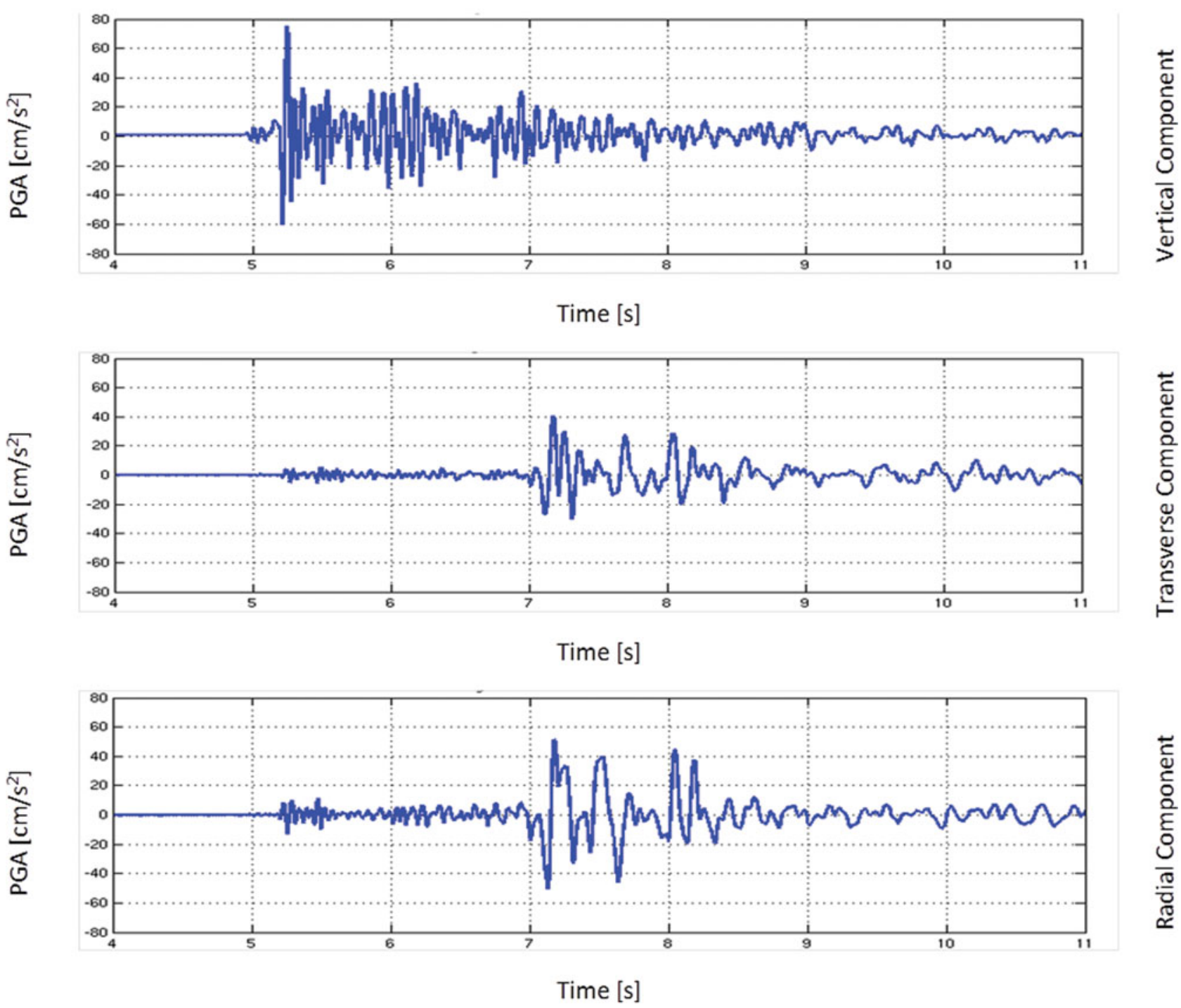

Fig. 2. Accelerogram of the earthquake near Huizinge recorded on 16 August 2012 by the accelerometer located near Westeremden (near the epicentre).

The PSHA methodology has been further developed since its inception in the 1960s (Calvi et al., 2006; Scawthorn, 2007, 2008; Bommer et al., 2015), and forms the basis of seismic risk assessments developed in the USA under the auspices of regulators like the National Research Council (NRC) and US Geological Survey (USGS). Also, the HAZUS risk assessment method and tools of the Federal Emergency Management Agency (FEMA) are based on a similar probabilistic method for seismic risk assessment. The method allows the assessed risk to be compared to safety norms set by society. For induced seismicity in the Netherlands, the norms were set by the 'Committee Meijdam' (Commissie-Meijdam, 2015).

Although the methodology used for the assessment of hazard and risk (PSHA) and the implementation (Monte Carlo) are based on standardised accepted and established processes, the hazard and risk assessment for induced seismicity in Groningen also contains innovations and adaptations to the local situation. Central to the probabilistic assessment of hazard and risk is the identification, quantification and consistent treatment of all uncertainties throughout the calculation chain of the Monte Carlo procedure. The data acquisition activities are critical for the assessment of the uncertainties and reduction of the epistemic uncertainty.

Detailed models were built of the Groningen gas reservoir (de Jager \& Visser, 2017; Visser \& Solano Viota, 2017) and these were calibrated with available and newly acquired pressure data, observations of water ingress into the gas reservoir and subsidence measurements (Van Eijs et al., 2017; Van Oeveren et al., 2017;). Based on geomechanical models of fault movement and the historical earthquake catalogue, seismological models were built (Bommer \& Van Elk, 2017; Dempsey \& Suckale, 2017; Zöller \& Holschneider, 2017) for induced seismicity in response to gas 


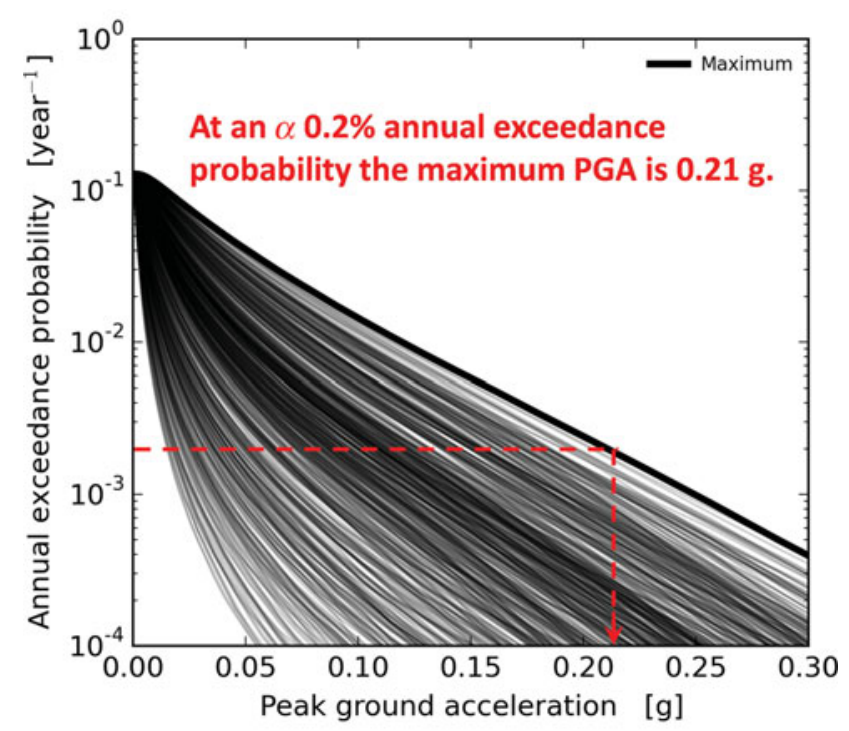

Fig. 3. An example of a set of hazard curves showing average annual exceedance rate for peak ground acceleration at different locations in the field. Each line corresponds to a location in the field. The bold line indicates the maximum PGA anywhere within the field for a given exceedance level (bounding envelope). The red line indicates that for an exceedance level of $0.2 \% a^{-1}$ the highest PGA in the field is $0.21 \mathrm{~g}$.

production scenarios. An expert panel using the SSHAC (Senior Seismic Hazard Analysis Committee) method estimated the maximum magnitude of an induced earthquake in Groningen (Harris \& Bourne, 2017; Zöller \& Holschneider, 2017).

Additionally, geomechanical studies (Burnett et al., 2016; Lele et al., 2016; Buijze et al., 2017;) and experiments on core material acquired in the Zeerijp-3A well (Hunfeld et al., 2017) have been carried out to gain a better understanding of the mechanism causing the earthquake ruptures.

Based on detailed models of the shallow subsurface (Kruiver et al., 2017a,b; Rodriguez-Marek et al., 2017; R.P. Noorlandt et al., unpublished work), ground motion prediction models have been developed for application to the Groningen earthquakes (Bommer et al., 2016, 2017 a,b). Besides the hazard posed by ground movement, the potential for liquefaction is also studied (Lasley et al., 2016, 2017).

To be able to assess the response of buildings to the induced earthquakes in Groningen, the study programme also included a civil engineering component. The properties of building material and building elements like single leaf walls and cavity walls have been tested in laboratory experiments (Graziotti et al., 2016a,b; Malome et al., in press). Several buildings have been tested at the shake tables of EUcentre (Pavia, Italy) (Graziotti et al., 2017) and LNEC (Lisbon, Portugal). Results of these experiments were used to calibrate computer models for different buildings and prepare fragility functions for different building typologies encountered in the Groningen area (Graziotti et al., 2017).

To ensure the research is carried out as objectively as possible, it is subjected to rigorous assurance. This process consists of seven layers, the most important of which are the assurance by the Scientific Advisory Committee (SAC) of the Minister of Economic Affairs and independent international experts (NAM et al., 2016a,b). Also transparency of the studies is important to allow external experts to form an opinion of the quality and objectivity of the studies. Study reports are published on a publicly accessible dedicated website (www.nam.nl/feiten-en-cijfers/onderzoeksrapporten), and seismic data are shared with interested academics. Currently some 70,000 downloads (as at 31 July 2017) have been made from the website, while data have been shared with 10 universities from all over the world. After publication on the website, the research is also published in peer-reviewed journals.

\section{Probabilistic assessment of the hazard resulting from induced seismicity}

\section{Hazard metric}

Because peak ground acceleration (PGA) is a widely used metric for ground-shaking intensity, it was chosen as the most appropriate hazard metric for this seismic hazard assessment. When extending the assessment to encompass risk (i.e. the response of buildings to ground shaking), spectral acceleration (SA) will be
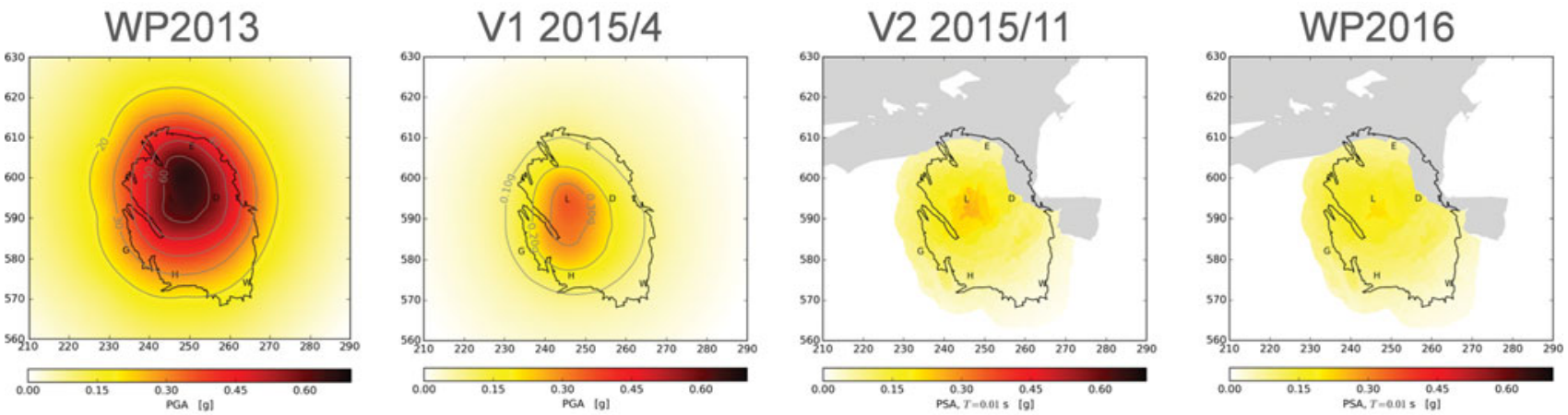

Fig. 4. Hazard maps published by NAM from 2013 to 2016, illustrating the development of the hazard maps while the research programme progressed. 
Table 1. Most relevant background data for the hazard maps published by NAM from 2013 to 2016.

\begin{tabular}{|c|c|c|c|c|}
\hline & WP 2013 & V1 & V2 & WP 2016 \\
\hline & November 2013 & April 2015 & November 2015 & April 2016 \\
\hline \multirow[t]{2}{*}{ Period } & January 2013-January & January 2016-July & January 2016-January & January 2016-January \\
\hline & 2023 & 2021 & 2021 & 2021 \\
\hline Production & $40 \mathrm{bcm}$ & $39.4 \mathrm{bcm}$ & $33 \mathrm{bcm}$ & $33 \mathrm{bcm}$ \\
\hline Seismicity model & Strain partititioning & Activity rate V1 & Activity rate V2 & Activity rate V2.5 \\
\hline GMM & Akkar et al. (2013) & Ground motion V1 & Ground motion V2 & Ground motion V2.5 \\
\hline Soil description & Soft soil omnipresent & Soft soil omnipresent & Detailed soil model & Detailed soil model \\
\hline Maximum PGA & $0.67 \mathrm{~g}$ & $0.35 \mathrm{~g}$ & $0.27 \mathrm{~g}$ & $0.22 \mathrm{~g}$ \\
\hline
\end{tabular}

$27 \mathrm{bcm}$

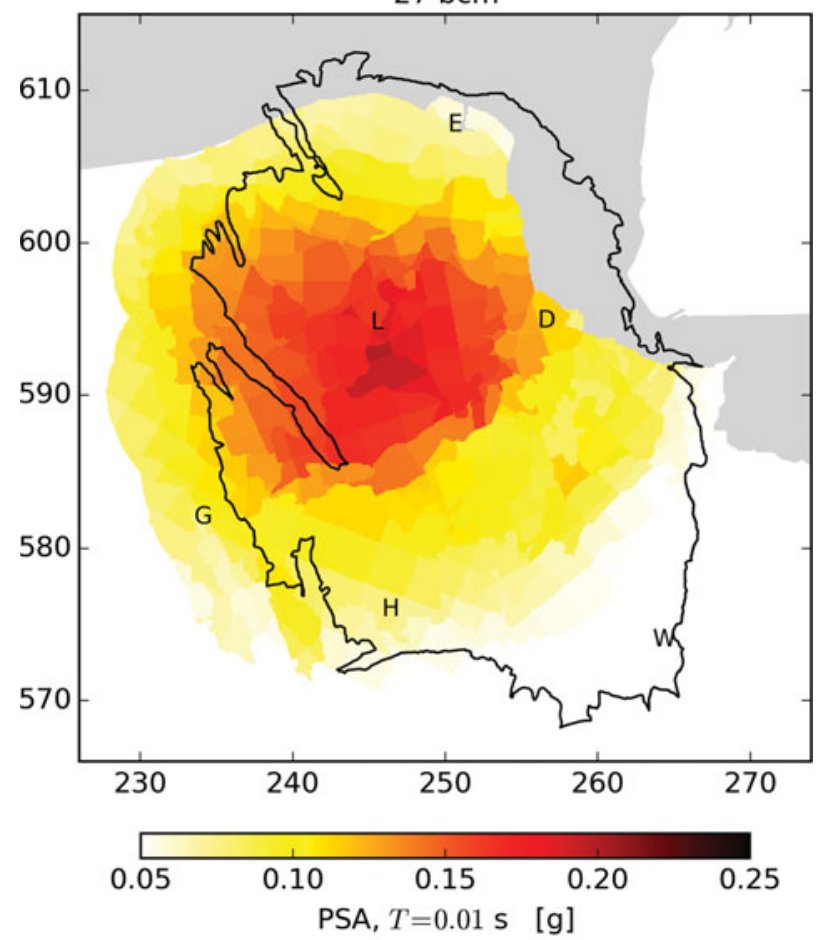

Fig. 5. PGA hazard maps. Period: 2016-2021; production: 27 bcm a ${ }^{-1}$; compaction: inversion; activity rate model: Version V2, $3.5 \leq M \leq 6.5$; metric: $0.2 \% a^{-1}$ chance of exceedance ( $10 \%$ chance in 50 years). Mean hazard from logic tree. The maximum PGA in this map is $0.21 \mathrm{~g}$.

used; this takes into account the response period of the building being considered. Figure 2 shows the measured acceleration near the epicentre during the Huizinge earthquake of $16 \mathrm{Au}$ gust 2012. In addition to the PGA values the duration of the events has also been incorporated in the ground motion prediction methodology, as this is also important for the seismic risk.

\section{Peak ground acceleration and hazard maps}

For the probabilistic description of the ground accelerations (PGA, or generalised to peak spectral acceleration, PSA), a haz- ard map is used. On this map for each location the acceleration is plotted that could occur, with a prescribed annualised probability of exceedance (exceedance level), during a prescribed analysis period. Hazard levels are shown using a gradual colour scale.

The hazard maps shown in the section were constructed according to the following procedure. Each location in the analysis area during the analysis period is subjected to ground motion accelerations resulting from induced earthquakes. At some locations, e.g. near Loppersum, the chance of exceeding a given peak ground acceleration threshold is higher than at the periphery of the field. Equally, at any one location, the chance of exceeding some value of peak ground acceleration decreases with increasing peak ground acceleration. An example of a set of hazard curves is shown for a number of locations in Figure 3. Each declining line indicates the hazard curve for a single location in the field.

To prepare a hazard map, an exceedance level needs to be chosen. This is not a purely technical choice. Inspired by Eurocode $8^{1}$, part of the current technical standards for structural design in Europe, it has become common practice to prepare hazard maps for an exceedance level of $0.2 \% \mathrm{a}^{-1}$. This exceedance level is equivalent to a 475-year return period for stationary seismicity. The same exceedance level is also used by KNMI for their hazard maps. Hazard maps can be made for different production scenarios. This return period is only used for representation of the hazard. The actual assessment of hazard and risk is not affected by this choice.

The hazard assessment critically depends on the modelling of reservoir pressure in response to gas withdrawal from the reser-

1 The Eurocodes are the current technical standards for structural design in Europe, and it is now compulsory for the 28 countries in the Eurocode zone to adopt these. Eurocode 8 specifically deals with earthquake-resistant design of structures (CEN, 2006). Each country adopting Eurocode 8 must develop a National Annex to indicate how the code is implemented; the National Annex for the Netherlands is being developed. Eurocode 8 uses a standard practice to represent seismic hazard via PGA maps associated with ground motions having a $10 \%$ probability of exceedance during 50 years, equivalent to $0.2 \% \mathrm{a}^{-1}$ for a stationary process, or a return period of 475 years. 

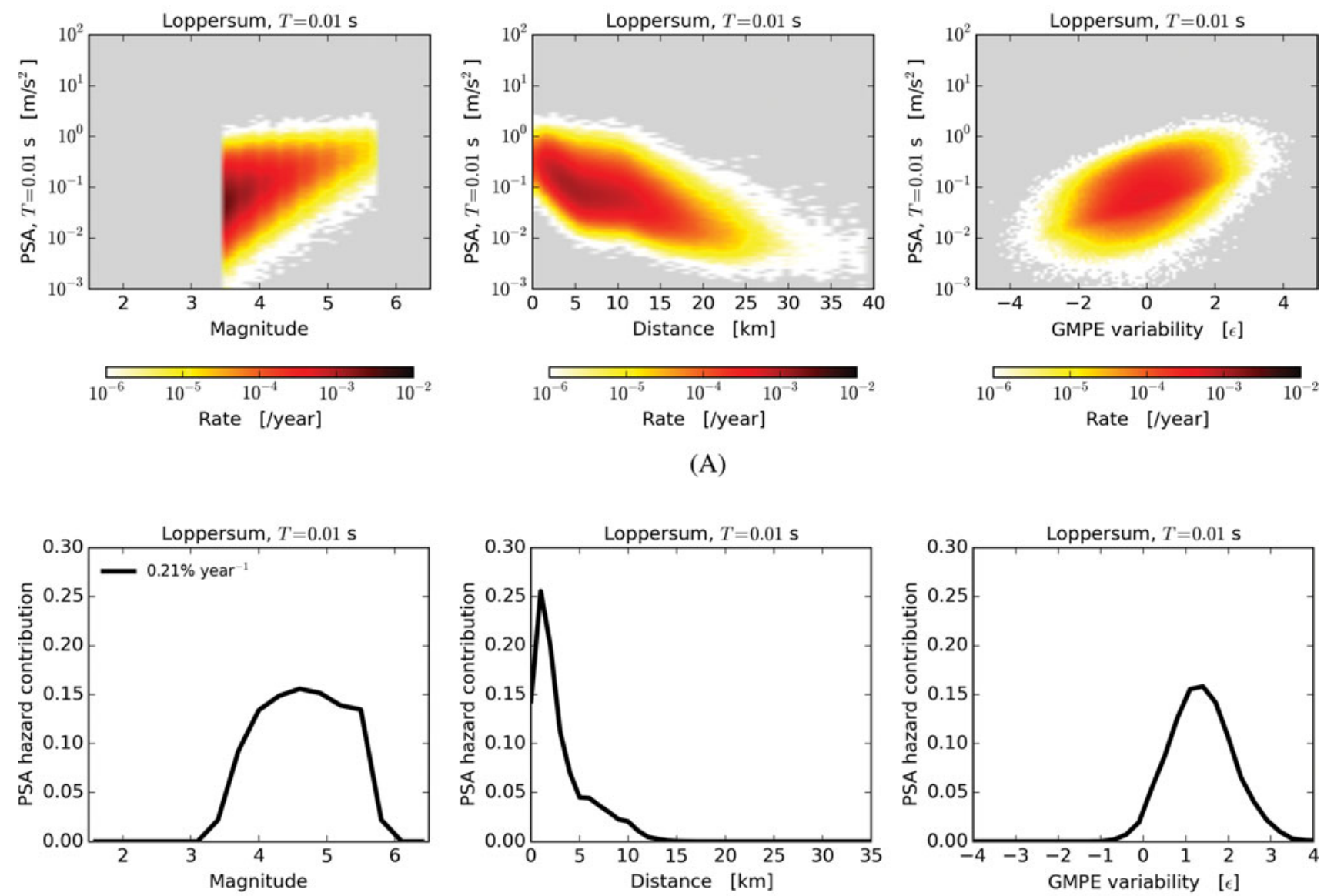

(A)

(B)

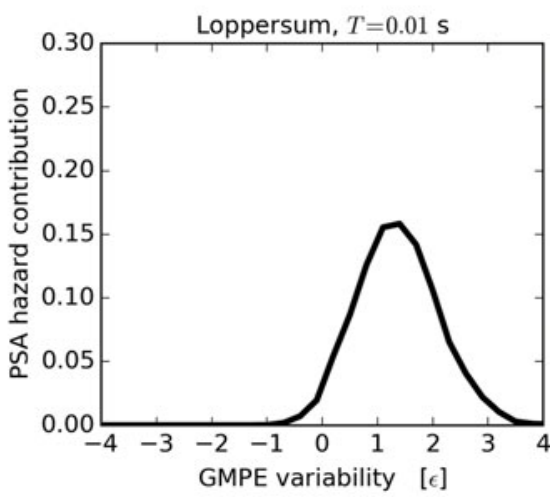

Fig. 6. (A) Occurrence rates for peak spectral acceleration at $0.01 \mathrm{~s}$ as a function of magnitude, distance and GMPE epsilon, $\varepsilon$, for a single surface location directly above the region of maximum reservoir compaction. Grey denotes no occurrence in any of the simulations. $(B)$ The fractional contribution to the ground motion with a $0.2 \%$ annual probability of exceedance from January 2016 to January 2021.

voir, the resulting reservoir compaction, assessed seismicity and the method to predict the motion at surface. During the study programme, progress was made in each of the areas of study. Together with the impact of lower annual gas production levels, this is reflected in the hazard maps that have been published while the studies progressed (Fig. 4).

The hazard map included in Winningsplan 2013 (NAM, 2013) used a method based on tectonic earthquakes in southern Europe to predict the ground motion. This map also assumed a soft soil to be present throughout the Groningen area. The hazard map published in November 2015 included the impact of the detailed mapping of the soil geology. Instead of smooth concentric hazard contours, the new contours now reflect variation in the soil properties. Table 1 gives an overview of the most important parameters for the hazard maps. Furthermore, with version 2 also assessment of the response spectra and seismic event duration was added. This allowed for more accurate estimation of the building response to a seismic event.

The impact of lateral heterogeneity in the composition of the shallow subsurface can clearly be seen in the hazard map.
The hazard map for the scenario of an annual field production of $27 \mathrm{bcm} \mathrm{a}^{-1}$, and the current offtake distribution is shown in Figure 5.

\section{Disaggregation of seismic hazard}

Disaggregation of the Monte Carlo results for the hazard assessment provides insight into which earthquakes have most impact on the hazard assessment at a given location. Examples of a disaggregation are shown in Figure 6 (for the Loppersum area) and Figure 7 (for the city of Groningen).

The disaggregation of the hazard for Loppersum shows that the largest contribution to the hazard is from earthquakes within the Loppersum area (small distance of less than $5 \mathrm{~km}$ away, with a magnitude ranging from 4 to 5). In contrast, the largest contribution to the hazard in the Groningen city is from earthquakes with an epicentre approximately $10 \mathrm{~km}$ away from the city (towards the Loppersum area). To cause significant ground acceleration in the city of Groningen, these earthquakes 

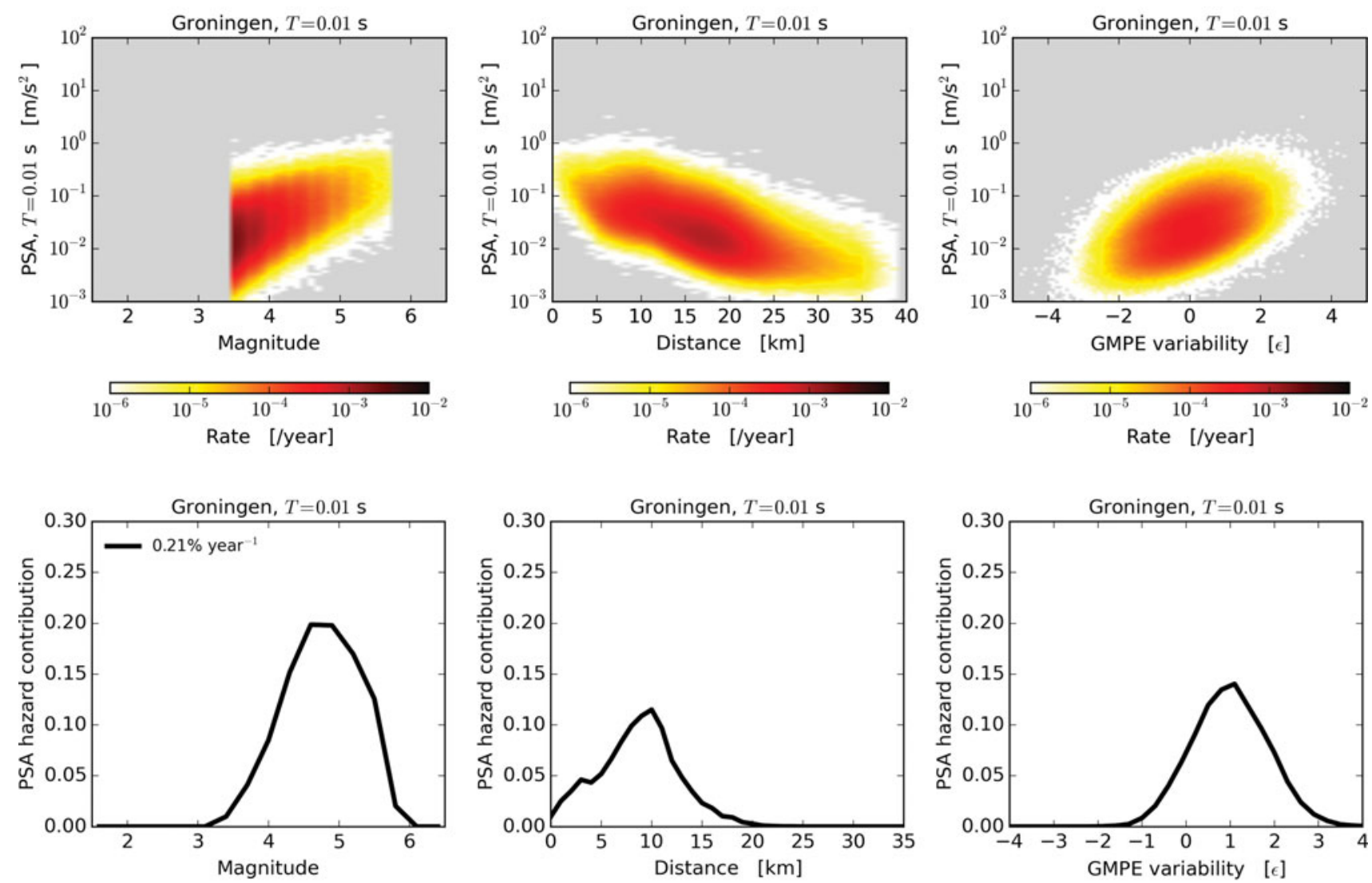

Fig. 7. As previous figure, except for a surface location in the centre of Groningen city.

located further away require a larger magnitude or GMPE epsilon to cause similar ground motions.

Sites with poor response $(\varepsilon \geq 0)$ contribute most to the hazard for the Loppersum area and the city of Groningen, with the largest contribution for $\varepsilon=1$.

\section{Probabilistic assessment of the risk resulting from induced seismicity}

\section{Risk metrics}

The results from the probabilistic hazard and risk analysis (PHRA) are summarised via risk metrics which are related to the annualised probability of fatality for an individual person or for groups of people, taken as an average across the forecast period of the PHRA. These risk metrics - 'Inside Local Personal Risk', 'Object-bound Individual Risk', 'Number of People at Risk', 'Community Risk, and 'Social Risk' - are defined below. 'Inside Local Personal Risk' and 'Object-bound Individual Risk' are individual risk metrics (related to probability of fatality for an individual), whereas the remaining three metrics are measures of aggregate risk (related to probability of fatality for multiple people or for groups of people).
When measuring risk, it is important to select a risk metric that is appropriate given the purpose of the risk measurement. In many cases there is more than one option available. An advisory committee, Commissie Meijdam, was established in early 2015 to advise on risk policy related to Groningen earthquakes, including the selection of risk metrics. In December 2015 the Commissie-Meijdam shared its third and final advice with the Minister of Economic Affairs. The selection of risk metrics for this PHRA reflects the final advice published by CommissieMeijdam (2015).

\section{Risk metric}

Both individual (related to probability of fatality for an individual) and aggregated (related to probability of fatality for multiple people or for groups of people) metrics have been used to describe the risk resulting from induced seismicity in Groningen. Individual risk metrics include 'Inside Local Personal Risk' and ‘Object-bound Individual Risk'. Aggregated risk metrics include 'Community Risk, 'Group Risk' and 'Social Risk'. In this paper we will focus on Inside Local Personal Risk (ILPR); the annual probability of fatality for a fictional person, who is continuously present without protection, inside a building. 

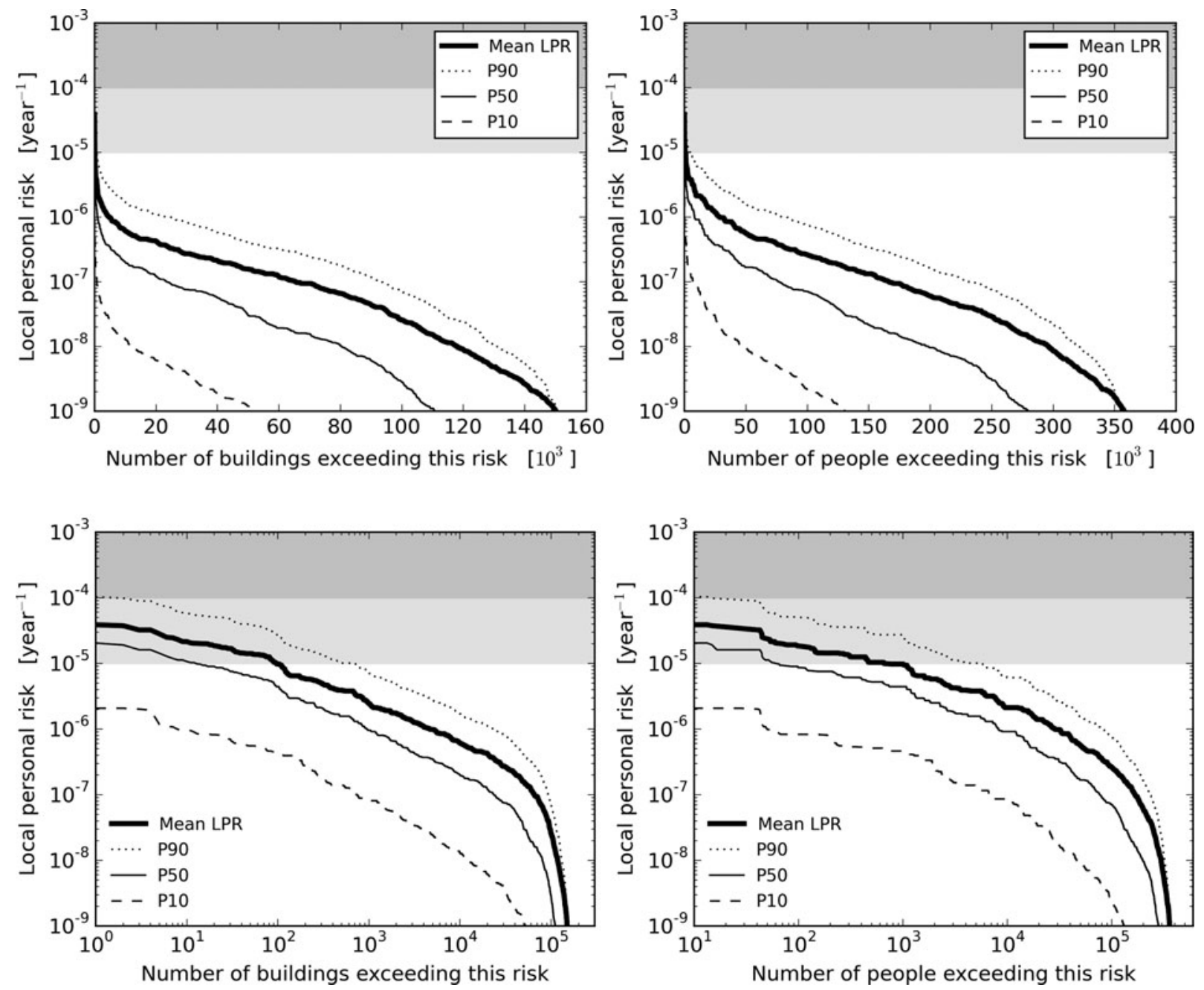

Fig. 8. Number of buildings and people exceeding a given ILPR shown on (top) a linear scale and (below) a log scale for the 27 bcm production scenario and the 2016-2021 assessment period. The grey areas indicate the norm advised by the Commissie-Meijdam.

Risk assessment for Inside Local Personal Risk (ILPR)

With knowledge of the presence of people in the buildings, the number of people exceeding an ILPR can be estimated. The solid black line in Figure 8 shows the number of people exposed to a certain level of local personal risk. During this 5-year period, there are no buildings where the occupants are exposed to a mean local personal risk larger than $10^{-4} \mathrm{a}^{-1}$. 0ccupants of some 100 buildings are exposed to a mean local personal risk exceeding $10^{-5} \mathrm{a}^{-1}$ in the period 2016-2021. Over the period 2021-2026 this increases with some 100 additional buildings. The uncertainty in the risk assessment indicates this could be as many as 1,000 buildings. As risk in this context is often plotted as a logarithmic quantity, the mean log local personal risk is also shown. The shaded grey areas indicate the norm set by the Commissie-Meijdam (2015).

The spatial distribution of buildings within given ranges of ILPR is shown in Figure 9 for an optimized production scenario of 27 billion $\mathrm{m}^{3}$ (bcm) $\mathrm{a}^{-1}$. Each of the approximately 160,000 occupied buildings within the exposure area is represented by a single dot. These are plotted in order of increasing risk so that the largest risks plot on top. Grey dots denote risks smaller than $10^{-6} \mathrm{a}^{-1}$.

When comparing these numbers with the norms advised by the Commissie-Meijdam, the second map is relevant. It shows the location of the buildings that do not meet this norm in the $27 \mathrm{bcm} \mathrm{a}^{-1}$ production scenario. As this is the result of a probabilistic assessment, it must be validated through inspections of buildings. These estimates do not include risk from nonstructural elements, which has been assessed through a separate methodology and is described in a separate risk metric for falling objects.

\section{Disaggregation of risk (ILPR)}

A disaggregation of contributions to the base-case ILPR was performed for magnitude, distance from the epicentre, the ground 
$10^{-4}<\mathrm{ILPR}<10^{-3}$

(buildings 0 )

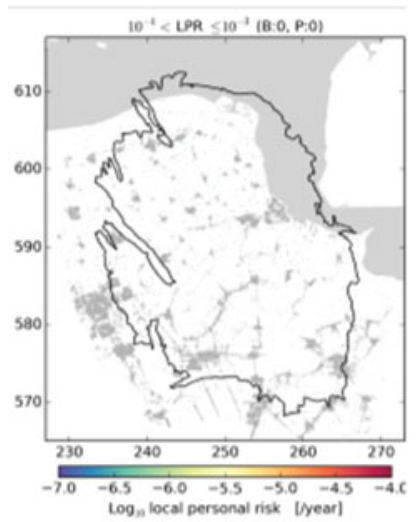

$10^{-5}<\mathrm{ILPR}<10^{-4}$

(buildings c. 100)

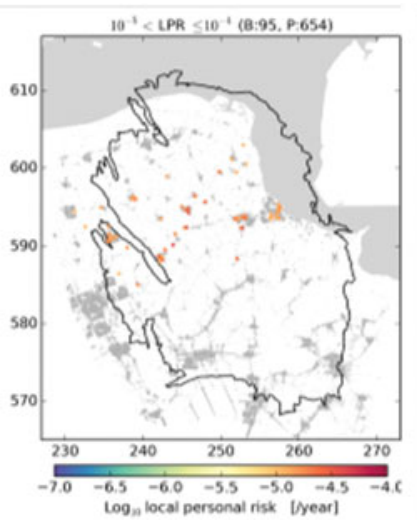

$10^{-6}<\mathrm{LLPR}<10^{-5}$

(buildings c. 5,000)

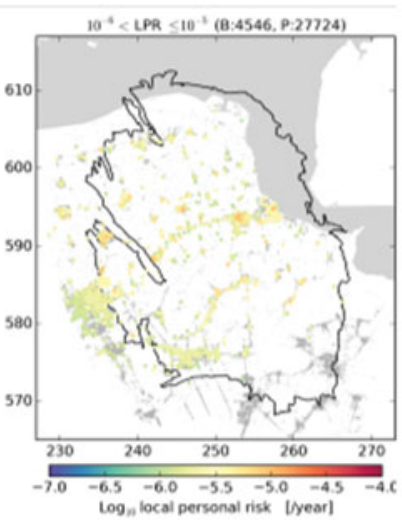

$10^{-7}<$ ILPR $<10^{-6}$

(buildings c. 60,000)

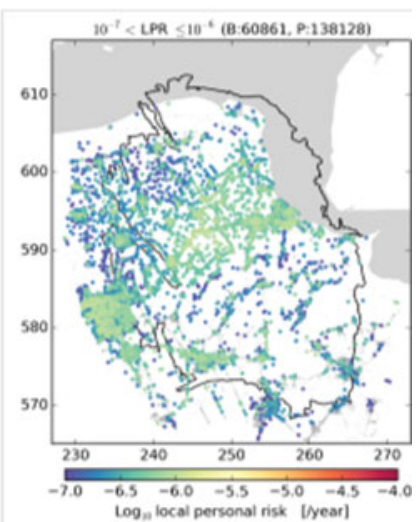

Fig. 9. ILPR for every individual building within four equal risk bands from $10^{-7}$ to $10^{3} \mathrm{a}^{-1}$ for the 5-year assessment period $2016-2021$ under the $27 \mathrm{bcm}$ production scenario.
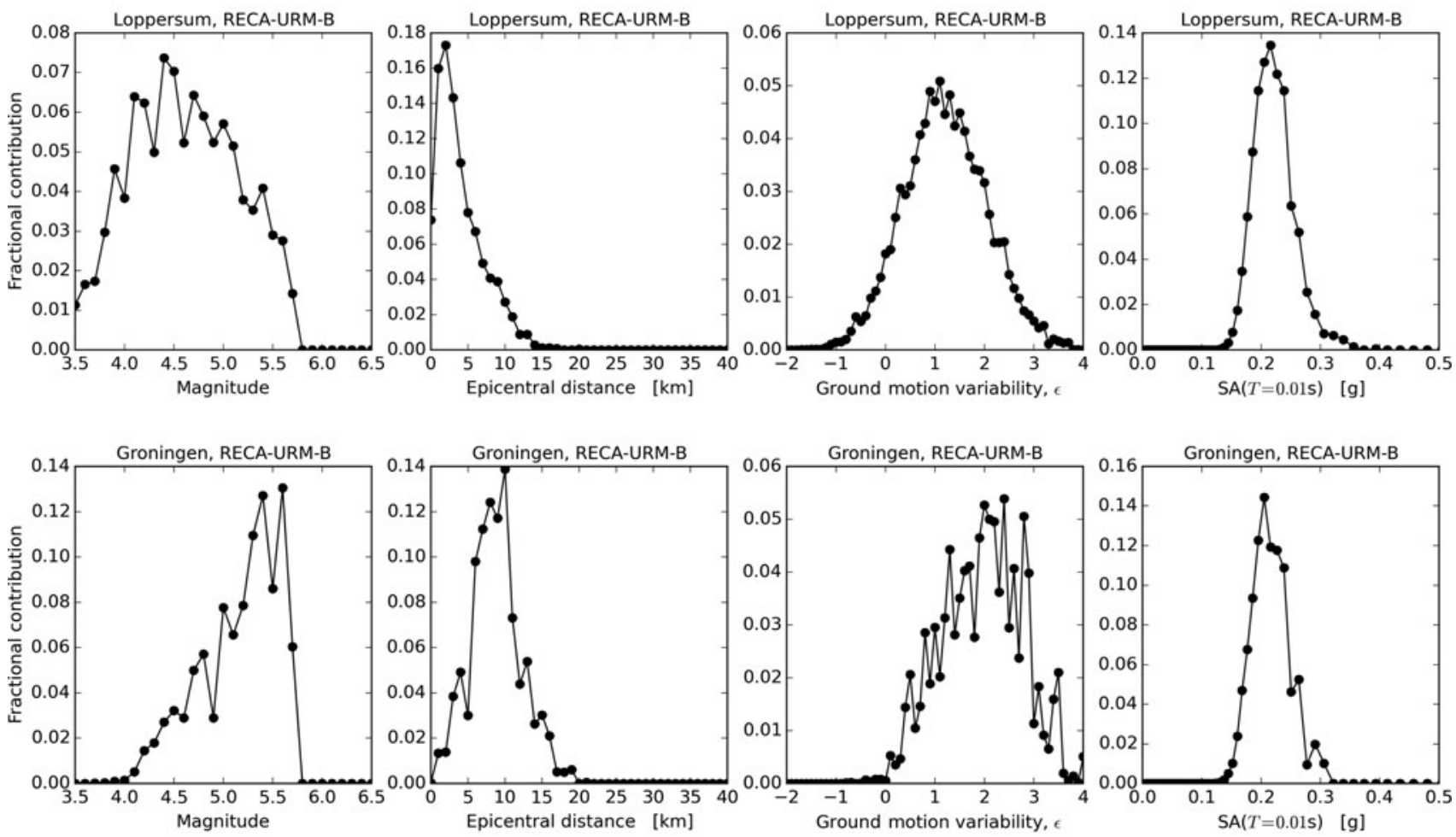

Fig. 10. The fractional contribution to ILPR for the RESA-URM-B building typology at two locations: Loppersum (top row) and Groningen city centre (bottom row). This result was obtained for the 2016-2021 assessment period under the $33 \mathrm{bcm} \mathrm{a^{-1 }}$ production scenario and the base-case scenario of the risk logic tree. Fluctuations between neighbouring points are due to finite sampling effects of the Monte Carlo procedure; nonetheless the underlying trends are clear.

motion variability measure $\varepsilon$, and spectral acceleration causing building collapse. As an example, Figure 10 shows the results for the residential apartment buildings of unreinforced masonry with silica-calcium load-bearing walls (type B) in the Loppersum area (typology RESA-URM-B).
As for hazard, earthquakes in the Loppersum area (i.e. at epicentral distances less than $5 \mathrm{~km}$ ) contribute most to the risk for this area. For Groningen city, earthquakes at an epicentral distance of $10 \mathrm{~km}$ (i.e. in the Loppersum area) are the most important contribution to the risk. 


\section{Structural upgrading as a mitigating option}

The estimate of the number of buildings exceeding an ILPR of $10^{-5}$ does not directly translate into an estimate of the scope of the building-strengthening effort. Reasons for a larger scope of the structural upgrading effort are:

- Efficiency of identifying buildings with ILPR $>10^{-5}$ has not yet been proven. This is a probabilistic assessment and does not directly indicate every individual building that needs to be included in the structural upgrading plan.

- Remaining uncertainty in hazard and risk assessment. Future updates of the hazard and risk assessment could result in a different mean value of the risk, for instance based on the results of shake table tests of a new typology of building, or where the small number of buildings subject to 'special circumstances' (e.g. buildings located on 'Wierden') is taken into account.

- Differences between the hazard and risk assessment and NEN-NPR building code. Ultimately the structural upgrading scope will be based on the NEN-NPR building code.

\section{Conclusions}

As part of the research programme started by NAM in 2013, assessments of hazard and risk resulting from the exposure to induced earthquakes have been prepared. While more data were collected in the Groningen area as the studies progressed, the models could be refined and the uncertainty in these assessments could be reduced. These assessments have been publicly shared and supported both Winningsplan 2013 and Winningsplan 2016.

\section{Acknowledgements}

Many people have contributed to this work, either directly or through very constructive and helpful discussions. In particular, the comments from the Scientific Advisory Committee led by Lucia van Geuns have been instrumental in improving this work. We also wish to thank the anonymous reviewers for helpful comments on the original version of this paper, and guest editor Karin van Thienen-Visser for assistance with processing this contribution.

\section{References}

Akkar, S., Sandikaya, M.A. \& Bommer, J.J., 2013, Empirical ground motion for point- and extended source crustal earthquake scenarios in Europe and Middle East. Bulletin of Earthquake Engineering 12: 359-387.

Bommer, J.J. \& van Elk., J., 2017. Comment on "The maximum possible and the maximum expected earthquake magnitude for production-induced earthquakes at the gas field in Groningen, The Netherlands' by Gert Zöller and
Matthias Holschneider. Bulletin of the Seismological Society of America 107(3): 1564-1567.

Bommer, J.J., Crowley, H. \& Pinho, R., 2015. A risk-mitigation approach to the management of induced seismicity. Journal of Seismology 19: 623-646.

Bommer, J.J., Dost, B., Edwards, B., Stafford, P.J., van Elk, J., Doornhof, D. \& Ntinalexis, M., 2016. Developing an application-specific ground-motion model for induced seismicity. Bulletin of the Seismological Society of America 106: 158-173.

Bommer, J.J., Dost, B., Edwards, B., Kruiver, P.P., Ntinalexis, M., RodriguezMarek, A., Stafford, P.J. \& van Elk, J., 2017a. Developing a model for the prediction of ground motions due to earthquakes in the Groningen gas field. Netherlands Journal of Geosciences / Geologie en Mijnbouw, this issue.

Bommer, J.J., Stafford, P.J., Edwards, B. Dost, B., van Dedem, E., RodriguezMarek, A., Kruiver, P. J., van Elk, J., Doornhof, D. \& Ntinalexis, M., 2017b. Framework for a ground-motion model for induced seismic hazard and risk analysis in the Groningen gas field, The Netherlands, Earthquake Spectra 33(2): 481-498.

Buijze, L., van den Bogert, P., Wassing, B.B.T., Orlic, B. \& ten Veen, J.H., 2017. Faulting mechanisms and dynamic rupture modeling of depletion induced seismic events in a Rotliegend reservoir. Netherlands Journal of Geosciences / Geologie en Mijnbouw, this issue.

Burnett, W., Gans, C., Gist, G., Terrell, M., Reilly, J., Tomic, J., Anderson, J., Tan, S., Dedontney, N. \& Pais, D., 2016. Applications of 3D elastic wavefield simulation to induced seismicity. Society of Exploration Geophysicists, International Exposition and Annual Meeting, 16-21 0ctober 2016, Dallas, Texas, USA. Conference proceedings. doi: 10.1190/segam2016-13950874.1.

Calvi, G.M., Pinho, R., Magenes, G., Bommer, J.J., Restrepo-Vèlez, L.F. \& Crowley, H., 2006. The development of seismic vulnerability assessment methodologies for variable geographical scales over the past 30 years. ISET Journal of Earthquake Engineering Technology 43(3): 75-104.

CEN, 2006. Eurocode I - Actions on Structures: Part 1 - 7 General Actions - Accidental Actions. European Committee for Standardisation (CEN).

Commissie-Meijdam, 2015. Eindadvies Handelingsperspectief voor Groningen Adviescommissie '0mgaan met risico's van geïnduceerde aardbevingen': $37 \mathrm{pp}$.

Cornell, C.A., 1968. Engineering seismic risk analysis. Bulletin of the Seismological Society of America 58(5): 1583-1606.

De Jager, J. \& Visser, C., 2017. Geology of the Groningen field - an overview. Netherlands Journal of Geosciences / Geologie en Mijnbouw, this issue.

Dempsey, D. \& Suckale, J., 2017. Physics-based forecasting of induced seismicity at Groningen gas field, the Netherlands. Geophysical Research Letters 44(15): 7773-7782. doi: 10.1002/2017GL073878.

Graziotti, F., Penna, A. \& Magenes, G., 2016a. A nonlinear SD0F model for the simplified evaluation of the displacement demand of low-rise URM buildings. Bulletin of Earthquake Engineering 14(6): 1589-1612.

Graziotti, F., Tomassetti, U., Penna, A. \& Magenes, G., 2016b. Out-of-plane shaking table tests on URM single leaf and cavity walls. Engineering Structures 125: 455-470.

Graziotti, F., Tomassetti, U., Kallioras, S., Penna, A. \& Magenes, G., 2017. Shaking table test on a full scale URM cavity wall building. Bulletin of Earthquake Engineering. doi: 10.1007/s10518-017-0185-8.

Harris, C.K. \& Bourne, S.J., 2017. Computing the distribution of Pareto sums using Laplace transformation and Stehfest inversion. Pure and Applied Geophysics 174: 2039-2075. 
Hunfeld, L.B., Niemeijer, A.R. \& Spiers, C.J., 2017. Frictional properties of simulated fault gouges from the seismogenic Groningen gas field under in-situ P-T-chemical conditions. Journal of Geophysical Research 122. doi: 10.1002/2017JB014876

Kruiver, P.P., van Dedem, E., Romijn, R., de Lange, G., Korff, M., Stafleu, J., Gunnink, J.L., Rodriguez-Marek, A., Bommer, J.J., van Elk, J. \& Doornhof, D., 2017a. An integrated shear-wave velocity model for the Groningen gas field, The Netherlands. Bulletin of Earthquake Engineering 15(9): 3555-3580.

Kruiver, P.P., Wiersma, A., Kloosterman, F.H., de Lange, G., Korff, M., Stafleu, J., Busscher, F., Harting, R., Gunnink, J.L., Green, R.A., van Elk, J., \& Doornhof, D., 2017b. Characterisation of the Groningen subsurface for seismic hazard and risk model. Netherlands Journal of Geosciences / Geologie en Mijnbouw, this issue.

Lasley, S.J., Green, R.A. \& Rodriguez-Marek, A., 2016. New stress reduction coefficient relationship for liquefaction triggering analyses. Journal of Geotechnical and Geo-environmental Engineering 142(11): 06016013. doi: 10.1061(ASCE)GT.1943-5606.0001530.

Lasley, S.J., Green, R.A. \& Rodriguez-Marek, A., 2017. Number of equivalent stress cycles for liquefaction evaluations in active tectonic and stable continental regimes. Journal of Geotechnical and Geo-environmental Engineering 143(4). doi: 04016116-1.

Lele, S.P., Hsu, S-Y., Garzon, J.L., DeDontney, N., Searles, K.H., Gist, G.A., Sanz, P.F., Biediger, E.A.O. \& Dale, B.A., 2016. Geomechanical modeling to evaluate production-induced seismicity at Groningen field. Society of Petroleum Engineers. Conference paper. doi: 10.2118/183554-MS.

Malome, D., Pinho, R. \& Penne, A., in press. Modelling the in-plane behaviour of URM walls by the applied element method. Earthquake Engineering and Structural Dynamics.

NAM, 2013. Winningsplan Groningen 2013, Nederlandse Aardolie Maatschappij BV (Assen). Available at www.nam.nl/feiten-en-cijfers.

NAM, 2014. Assessment for the Hazard Eemskanaal area of the Groningen field. Nederlandse Aardolie Maatschappij BV (Assen). Available at www.nam.nl/ feiten-en-cijfers.

NAM, 2015a, Hazard and risk assessment for induced seismicity in Groningen, Part I Hazard Assessment and Part II Risk Assessment. Nederlandse Aardolie Maatschappij BV (Assen). Available at www.nam.nl/feiten-en-cijfers.

NAM, 2015b. Hazard and risk assessment for induced seismicity in Groningen interim update. Nederlandse Aardolie Maatschappij BV (Assen). Available at www.nam.nl/feiten-en-cijfers.

NAM, 2016, Winningsplan Groningen 2016. Nederlandse Aardolie Maatschappij BV (Assen). Available at www.nam.nl/feiten-en-cijfers.
NAM, van Elk, J. \& Doornhof, D., 2012. Study and data acquisition plan induced seismicity in Groningen. Nederlandse Aardolie Maatschappij BV (Assen). Available at www.nam.nl/feiten-en-cijfers.

NAM, van Elk, J. \& Doornhof, D., 2014. Study and data acquisition plan induced seismicity in Groningen for the update of the Winningsplan 2016. Nederlandse Aardolie Maatschappij BV (Assen). Available at www.nam.nl/feiten-en-cijfers.

NAM, van Elk, J. \& Doornhof, D., 2016a. Study and data acquisition plan induced seismicity in Groningen update post-Winningsplan 2016 - Part 1 and 2. Nederlandse Aardolie Maatschappij BV (Assen). Available at www.nam.nl/ feiten-en-cijfers.

NAM, van Elk, J. \& Doornhof, D., 2016b. Study and data acquisition plan induced seismicity in Groningen update post-Winningsplan 2016 - progress and schedule. Nederlandse Aardolie Maatschappij BV (Assen). Available at www.nam.nl/feiten-en-cijfers.

Rodriguez-Marek, A., Kruiver, P. P., Meijers, P., Bommer, J.J., Dost, B., van Elk, B. \& Doornhof, D., 2017. A regional site-response model for the Groningen gas field. Bulletin of the Seismological Society of America. 107(5): 20672077.

Scawthorn, C., 2007. A brief history of seismic risk assessment. In: Bostrom A., French S.P. \& Gottlieb S.J. (eds): Risk assessment, modelling and decision support: strategic directions. Springer-Verlag (Heidelberg, New York and Tokyo): 5-81.

Scawthorn, C., 2008. History of seismic risk analysis. 14th World Conference on Earthquake Engineering, 12-17 0ctober 2008, Beijing, China. Paper no. 100036. Conference proceedings.

Tomale, M., 2015. Bevingen - aardbevingen in Groningen - gevolgen, ervaringen, emoties. Leander Uitgeverij (Beijum): $256 \mathrm{pp}$.

Van Eijs, R., van der Wal, O. \& Doornhof, D., 2017. Fieldwide compressibility estimation through inversion of subsidence data above the Groningen gas field. Netherlands Journal of Geosciences / Geologie en Mijnbouw, this issue.

Van Oeveren, H.E.J., Valvatne, P., Geurtsen, L.E. \& van Elk, J., 2017. History match of the Groningen Field dynamic reservoir model to subsidence data and conventional subsurface data. Netherlands Journal of Geosciences / Geologie en Mijnbouw, this issue.

Visser, C. \& Solano Viota, J., 2017. Introduction to the Groningen static reservoir model. Netherlands Journal of Geosciences / Geologie en Mijnbouw, this issue.

Zöller, G. \& Holschneider, M., 2017. The maximum possible and the maximum expected earthquake magnitude for production-induced earthquakes at the gas field in Groningen, The Netherlands. Bulletin of the Seismological Society of America 106(6): 2917-2921. 